\section{PENDIDIKAN AFEKTIF DALAM PERSPEKTIF HASAN LANGGULUNG}

\section{Mursal}

Pusat Bahasa Uin Suska Riau

\section{Abstract}

Dunia pendidikan di Indonesia saat ini telah menghadapi problem yang sangat kompleks. Hal ini dapat dilihat dari rendahnya kualitas pendidikan dari beberapa indikator diantaranya lulusan sekolah dan Perguruan Tinggi yang belum siap memasuki dunia kerja, sikap kalangan eksekutif, yudikatif dan legislatif yang kurang peduli terhadap permasalahan negeri ini. Permasalahan di atas dikarenakan pendidikan yang ditawarkan di sekolah-sekolah masih mementingkan aspek kognitif. Padahal ada aspek lain yang penting untuk dididik yaitu aspek afektif. Rumusan masalah dalam tulisan ini adalah bagaimana pendidikan afektif menurut Hasan Langgulung. Tulisan ini mempokuskan objek kajiannya pada sumber-sumber teoretis. Metode pengumpulan data dengan menggunakan metode dokumentasi, dan teknik analisis data dengan menggunakan content analiysis dengan cara deskriftif analitik. Pendidikan afektif menurut Hasan Langgulung dapat dilakukan di lingkungan keluarga dan sekolah dengan metode pembiasaan, amsal/contoh, keteladanan, suruhan, pengawasan, bimbingan, dan latihan.

\section{Pendahuluan}

Dunia pendidikan di Indonesia telah menghadapi problem yang cukup berat. Hal ini bisa kita lihat dari rendahnya kualitas pendidikan Indonesia, lebih memperhatikan lagi jika kita tinjau dari segi ahlak dan moralitas bangsa kita hal ini bisa kita lihat belakang-belakangan ini gejala kemerosotan moral benar-benar telah mengkhawatirkan. Masalah ini bukan hanya menimpa kalangan orang dewasa dalam berbagai jabatan dan profesinya, melainkan juga telah menimpa kalangan pelajar yang diharapkan dapat melanjutkan perjuangan bangsa. ${ }^{1}$

${ }^{1}$ Kunandar, Guru Propesional Implementasi Kurikulum Tingkat Satuan Pendidikan (KTSP) dan Dalam Sertifikasi Guru (Jakarta : Rajawali Press, 2007), hlm. 2
Di sisi lain, para pelaku pembangunan di bumi Indonesia ini dari kalangan legislatif, eksekutif, dan yudikatif, yang juga menunjukkan perangai yang jauh dari aspek sikap yang baik. ${ }^{2}$ Dan sikap mereka tersebut berimplikasi kepada rusaknya moralitas, seperti Kasus dugaan korupsi dan lain sebagainya. ${ }^{3}$

Permasalahan rendahnya kualitas pendidikan kurang responnya kalangan pemerintahan terhadap permasahan tersebut, dikarenakan pendidikan yang ditawarkan di dalam sekolah-sekolah masih bersipat mementingkan pengetahuan (kognitif) dan aspek psikomotor saja padahal ada aspek yang lain yang sangat perlu dikembangkan yaitu aspek afektif. pendidikan afektif sangat membutuhkan suatu tatanan konsep pendidikan yang tidak saja luas cakupanya dan materinya, tetapi juga secara motodologinya (pendekatanya).

\section{Biografi dan Riwayat Hasan Langgulung}

Nama lengkap Hasan Langgulung adalah Prof Dr Hasan Langgulung. ${ }^{4}$ Ia lahir di Rappang, Sulawesi Selatan pada tanggal 16 Oktober 1934 M Indonesia. Ayahnya bernama Langgulung dan ibunya bernama Aminah Tansaruh. ${ }^{5}$ Dan ia merupakan seorang tokoh pendidikan di Indonesia yang telah lama berdomisili di Malaysia. ${ }^{6}$

Perjalanan pendidikan di mulai sejak ia hijrah ke timur tengah untuk menempuh pendidikan sarjana muda atau Bachelor Of Arts (BA) yang spesialisasi Islamic and Arabic Studiens yang beliau peroleh dari Fakultas Dar al-ulum, Cairo University, Mesir pada tahun 1962. setahun kemudian ia sukses menggondol gelar Diploma of Education (General) dari Ein Shams University, Kairo. Di Ein Shams University Kairo pula ia mendapat gelar M.A. dalam bidang Psikologi dan Kesehatan Mental (Mental Hygiene) pada

${ }^{2}$ http/ , Korupsi, diakses hari Rabu 20 April 2011

3 Indonesia Educational Statistic in Brief 2000/2001: Balitbang Depsiknas (dikutif dari harian Media Indonesia, 28 Maret 2011.

${ }^{4}$ Omar Muhammad al-Toumy al-Syaibany, Falsafah Pendidikan Islam, Terj Hasan Langgulung, (Jakarta: Bulan Bintang, 1979), hlm. 641

5 Who's Who in The Word, 7 Edition 1984-1985, (Chicago IIIiniois: Marquis Who's Who Incorporated, 1984), hlm. 595

${ }^{6}$ Hasan Langgulung, Pendidikan dan Peradaban Islam, (Jakarta: al-Husna Zikra,1985), hlm. 284 
tahun 1967. sebelumnya, ia juga sempat memperoleh Diploma dalam bidang Sastra Arab Moderen dari Intitute of Higher Arab Studies, Arab League, Kairo, yaitu di tahun 1964. kecintaanya kepada ilmu pengetahuan membuat ia berngakat ke Barad, Hasil gelar Doctor of Philosophy (ph.D) dalam Psikologi diperoleh dari University of Georgia, Amerika Serikat tahun 1971.

Hasan Langgulung juga Merupakan penggagas pendiri Fakultas Pendidikan di UKM tahun 1972. Selesai di UKM, beliau lalu pindah dan mendirikan Fakultas Pendidikan di IIUM tahun 1980-an. Meski lama hidup di Malaysia, hingga ahir hidupnya Hasan Langgulung masih teguh memegang kewarganegaraan Indonesia. ${ }^{8}$

\section{Karya-karya Hasan Langgulung.}

Adapun karya Hasan Langgulung banyak seklai diantaranya berbentuk tesis dan disertasi, buku-buku ilmiah maupun artikel-artikel ilmiah tesisnya adalah Al-Murabiq al-Indonesy; Ittijabatuh wa Darojatutawafuq indabu' yang merupakan tesis M.A nya di Ein Shams University, Cairo, 1967. sedangkan Diseratasinya berjudul A Cross- Cultural Study of The Child's Conception of Situational Causality in India, Westrn, Samoa, Mexico, and The United States, yang merupakan Disertasi ph.D nya di Universitas Georgia, Amerika Serikat, 1971. ${ }^{10}$

Adapun Buku-buku Hasan Langgulung yang sudah terbit adalah sebagai berikut:

1. Beberapa Aspek Pendidikan di Tinjau dari Segi Islam, Kuala Lumpur : Majalah Azzam, 1974.

2. Beberapa tinjauan dalam Pendidikan Islam, Pustaka Antara, Kuala Lumpur 1981

3. Peranan Ibu Bapak dalam Pendidikan Keluarga, Kuala Lumpur : AlIhsan, 1977.

7 Hasan Langulung, Asas-asas Pendidikan Islam, (Jakarta: Pustaka al-Husna Baru, 2003), Cet,V. hlm. 413-414.

${ }^{8} \mathrm{Ibid}$, hlm. 18

9 Ibid., hlm. 254

${ }^{10}$ Ibid., hlm. 284. dapat juga dilihat karya Hasan Langgulung, Teori-teori Kesehatan Mental, (Jakarta: al-Husna Zikra, 1986), hlm. 465.
4. Falsafah Pendidikan Islam, Terjemahan dari karya Omat Muhammad al-Thoumy al-Syaibany, Jakarta : Bulan Bintang, 1979.

5. Beberapa Pemikiran tentang Pendidikan Islam, Bandung : AlMa'arif, 1980

6. Pendidikan dan Moral, Kuala Lumpur: Dewan Masyarakat, 1977.

7. Al-Ghazali dan bnu Thufail Vs Reusseu dan Pioget Kuala Lumpur :Majalah Jihad, 1976.

8. Pendidikan Islam akan Kemana ? Kuala Lumpur : Cahaya Islam, 1977

9. Peralihan Paradigma dalam Pendidikan Islam dan Sains Sosial, Jakarta: Gaya Media Pratama, 2002

10. Asas-asas Pendidikan Islam, Jakarta : Pustaka Al-Husna Baru, 2003 Edisi Revisi ( Cet V)

11. Pendidikan Islam dalam Abad 21, Jakarta: Pustaka Al-Husna Baru, 2003, Edisi Revisi ( Cet,III ).

12. Statistik dalam Psikologi dan Pendidikan, Pustaka Antara, Kuala Lumpur 1983.

13. Pendidikan dan peradaban Islam, Jakarta Pustaka al-Husna, 1985.

14. Manusia dan Pendidikan, Suatu Analisa Psikologi dan pendidikan, Jakarta, Al-Husna Zikra, 1986.

15. Teori-teori Kesehatan Mental, Jakarta : Pustaka al-Husna Zikra, 1986

16. Kreatifitas dan Pendidikan Islam; Analisa Psikologi dan Pendidikan Islam, Jakarta : Pustaka Al-Husna, 1991.

17. Issu-issu Semasa dalam Psikolog, Pustaka Huda (dalam percetakan )

18. Falsafah Kurikulum Sekolah Rendah, Pustaka Huda ( dalam percetakan

19. Psikologi dan Kesehatan Mental di Sekolah-Sekolah, UKM, Malaysia, 1979.

\section{Pendidikan Afektif}

Pendidikan menurut Hasan Langgulung adalah suatu proses yang mempunyai tujuan yang biasanya diusahakan untuk menciptakan pola-pola 
tingkah laku tertentu pada kanak-kanak atau orang yang sedang dididik. ${ }^{11}$ Ia juga mengungkapkan bahwa pendidikan adalah suatu tindakan (action) yang diambil oleh suatu masyarakat, kebudayaan atau peradaban untuk memelihara kelanjutan hidupnya. ${ }^{12}$ Pendidikan dapat ditinjau dari tiga segi. Yang pertama dari sudut pandang individu, kedua dari sudut pandang masyarakat, ketiga dari segi individu dan masyarakat sekaligus, atau hasil interaksi antara individu dan masyarakat. ${ }^{13}$

Dari segi pandangan individu beranggapan bahwa manusia hidup di atas dunia ini mempunyai sejumlah atau seberkas kemampuan melihat dan mendengar yang sifatnya umum pada setiap manusia, sama umumnya dengan kemampuan memelihat dan mendengar, tetapi berbeda dalam derajat masing-masing seperi halnya panca indra juga. Ada yang penglihatannya kuat, tetapi pendengarannya lemah, begitu seterusnya.. ${ }^{14} \mathrm{Jad}$ pendidikan dalam konteks ini adalah menampakkan yang tersembunyi pada diri anak-anak itu, yaitu aspek seperti kecerdasan, kepribadian, dan lain-lain.

Dalam prespektif masyarakat, diakui bahwa manusia memiliki kemampuan-kemampuan asal, tetapi tidak dapat menerima bahwa anakanak itu memiliki benih-benih bagi segala yang telah dapat dicapai oleh manusia. Ia menekankan kepada kemapuan manusia memperoleh pengetahuan yang dengan mencarinya pada alam diluar manusia. ${ }^{15}$.

Dari uraian di atas dapat ditarik kesimpulan bahwa pendidikan itu mempunyai tiga pedekatan. Pendekatan pertama menganggap pendidikan sebagai pengembangan potensi, pendekatan kedua pendidikan merupakan pewarisan budaya, sedangkan pendekatan ketiga menganggap pendidikan merupakan sebagai interaksi antara potensi dan budaya.

Afektif merupaan nilai (value). Nilai itu adalah suatu konsep yang berada dalam pikiran manusia yang sifatnya tersembunyi, tidak berada dalam

${ }^{11}$ Hasan Langgulung, Manusia dan pendidikan suatu analisa psikologi dan pendidikan, (Jakarta : al-husna Zikra, 1996), hlm. 32

12 Hasan Langgulung, Beberapa Pemikiran Tentang Penidikan Islam, ( Bandung : Pustaka al-Zikra, 1980), hlm. 93-94

${ }^{13}$ Hasan Langgulung, Kreativitas dan Pendidikan Islam Analisa Psikologi dan Falsafah, (Jakarta : Pustaka al-Zikra, 1991), hlm. 359

${ }^{14}$ Ibid.

${ }^{15}$ Ibid. dunia empiris. Nilai berhubungan dengan pandangan seseorang tentang baik buruk, indah dan tidak indah, layak dan tidak layak, adil dan tidak adil dan sebagainya. ${ }^{16}$

Nilai bagi seseorang tidak statis, akan tetapi selalu berubah. Setiap orang akan menganggap sesuatu itu baik sesuai dengan pandangnya pada saat itu. Oleh sebab itu, maka sistim nilai yang ada dalam diri seseorang bisa dibina dan diarahkan. Apabila seseorang menganggap nilai agama diatas segalanya, maka nilai-nilai yang lain akan bergantung kepada agama itu. ${ }^{17}$

Pembentukan afektif/sikap dimulai sejak anak dilahirkan. Karena, pada pase ini anak akan menjadikan orang tuanya sebagai model dalam perilaku sehari hari. Berarti, semakin banyak model yang diberikan contoh kepadanya, maka, semakin banyak pula sikap dan pengalaman yang mempengaruhi pembentukan kepribadiannya. ${ }^{18}$

Pendidikan afektif/sikap haruslah dilakukan dengan pengulangan dan peneguhan. Sebab ketika dilakukan peneguhan dan pengulangan akan berubah menjadi penghayatan tentang sikap atau nilai tersebut. Nila tersebut haruslah mempunyai model yang berarti tempat dimana nilai itu melekat. Cohtohnya kejujuran nilai itu tidak abstract tidak dapat diraba. Pendeknya supaya nilai yang bernama kejujuran itu dapat disaksikan dan beroperasi maka ia harus melekat pada suatu model, seorang guru, bapak, ibu dan lain-lain.

\section{Pendidikan Afektif dilingkungan Sekolah}

Adapun pendidikan afektif menurut Hasan Langgulung dilingkungan sekolah-sekolah dapat dirumuskan sebagai berikut: pertama tujuan, kedua materi (kandungan ), ketiga metode, keempat penilaian ( evaluasi ). ${ }^{19}$

a. Tujuan 
Adapun tujuan ${ }^{20}$ ahir pendidikan agama menurut Hasan Langgulung adalah persiapan bagi kehidupan dunia dan ahirat, sedangkan tujuan umum pendidikan agama adalah "pengembangan rasa cinta pada agama dan ahlak". ${ }^{21}$ Di dalam tujuan pendidikan ini aspek yang paling diutamakan andalah sikap pesrta didik.

\section{b. Materi/ isi}

Adapun materi ${ }^{22}$ pelajaran yang diterapkan di dalam sekolah-sekolah adalah materi pelajaran itu dimulai dengan tujuan -tujuan tersebut yaitu pengembangan rasa cinta pada agama dan ahlak. Maksudnya adalah silabus dibuat harus sesuai dengan tujuan ahir dan tujuan umum. Dan silabussilabus tersebut harus dapat memberikan pengajaran kepada murid-murid tentang masalah-masalah emosi yang dialaminya. Pendeknya silabus itu dapat digunakan. Namun, guru harus menghubungkan dengan tujuan ahir dan tujuan umum tersebut. ${ }^{2.3}$

\section{c. Metode $^{24}$}

Metode sebenarnya jalan untuk mencapai tujuan. Jadi, jalan itu bermacam-macam, begitu juga dengan metode tidak ada metode yang baik dalam semua mata pelajaran. Mungkin ada metode yang baik untuk

${ }^{20}$ Kawasan yang berkenaan dengan tujuan pendidikan sangat erat kaitanya dengan metafisika, dalam falsafah umum sebab ia memperbincangkan perkara-perkara seperti aspek spiritual manusia, nasib manusia sudah mati, hari ahirat. Hasan Langgulung, Manusia dan Pendidikan..., hlm. 51

${ }^{21}$ Hasan Langgulung, Beberapa Pemikiran ..., hlm. 179

22 Kawasan yang berkenaan dengan kandungan/isi pendidikan erat kaitanya dengan salah satu pembahasan salah satu pembahasan falsafah umum yaitu teori ilmu pengetahuan (epistemology).memang kandungan pendidikan harsulah pengetahuan, semua filosof setuju dengan itu.perbedaan pendapat terletak kepada ilmu yang mana, sebab ada ilmu naqli dan aqli dan lain lagi.malah itu alat, yang dalam istilah modern disebut keterampilan, yaitu ilmu yang memperlajari tentang ilmu yang lain, jadi bukan menjadi tujuan. Hasan Langgulung, Manusia dan Pendidikan .... hlm. 67

${ }^{23}$ Ibid., hlm. 183

${ }^{24}$ Semua metode-metode pendidikan yang disebutkan itu ada nas dalilnya dari alQur;an dan Hadits, untuk memudahkan pembaca dalam membaca dapat dilihat pada, alSyaibani, Falsafah Pedidikan Islam, terj, Hasan Langgulung, (Jakarta: Bulan Bintang, 1979), hlm. 549-619 pelajaran tertentu dan guru tertentu dan ada juga metode yang kurang baik dalam pelajaran dan guru tertentu.

Pelajaran agama sendiri bukan hanya satu segi saja. Ada segi kognitif seperti tentang fakta-fakta sejarah, syarat-syarat syah sembahyang, zakat, puasa dan haji ini adalah fakta yang tidak berubah. Namun yang perlu diperhatikan dalam pembelajaran agama adalah tentang kawasan afektifnya.. Seperti tujuan pendidikan agama diantaranya adalah untuk menumbuhkan rasa cinta kepada al-Qur’an, menghormati dan mengamalkan ajaranajarannya. ${ }^{25}$ Kawasan ini semua termasuk dalam pendidikan afektif. Menumbuhkan rasa cinta terhadap al-Qur'an boleh melalui musabaqah, membaca dan mau mendengarkan penafsirkan al-Qur'an atau bisa dengan mendengarkan orang lain membaca al-Qur'an atau dan mau mendengarkan maknanya tatsirnya atau mungkin bisa dengan mempertandingkan antar murid-murid yang bertemakan al-Qur'an.

Adapun mengembangkan sikap kepada agama dan ahlak menuut Hasan Langgulung bisa dillakukan sebagai berikut:

a) memperkenalkan kepada murid murid tentang akidah, dasar-dasar dan pokok-pokok ibadat dan cara mengerjakanya dengan membiasakan mereka mematuhi, menjalankan, dan menghormati akidah dan syi'ah agama

b) menumbuhkan kesadaran yang betul pada pelajar tentang agama dan apa yang terkantung di dalamnya tentang prinsip-prinsip ahlak yang mulia, dan menyadarkan tentang bid'ah dan khurafat-khurafat yang tidak ada hubungannya dengan Islam

c) menanamkan keimananan kepada Allah, pencipta alam, Malaikat, Rasul-Rasul, kitab-kitab, dan hari ahirat berdasarkan pada kesadaran dan kecintaan

d) mengembangkan minat-minat murid untuk memperdalam tentang adab kesopanan dan pengetahuan agama, dan mengikuti ajaran agama dengan kerelaan dan kecintaan

e) menanamkan rasa cinta terhadap al-Qur'an, dengan menghormati, membaca dengan baik, memahami dan mengajarkanya

\footnotetext{
${ }^{25}$ Hasan Langgulung, Beberapa Pemikiran ..., hlm. 183
} 
f) menumbuhkan rasa rela, optimisme, kepercayaan diri, memikul tanggung jawab, menghormati tugas, kerjasama atas kebaikan dan taqwa, kasih sayang, menginginkan kebaikan bagi orang lain, kesabaran, berjuang untuk kebaikan, berpegang teguh terhadap prinsip, suka berkorban dan membela agama dan tanah air

g) mendidik naluri-naluri, penggerak-penggerak, dan keinginan murid-murid dan mengokohkanya dengan akidah nilai-nilai dan membiasakan mereka menaham penggerak-penggeraknya dan mengatur dan membimbingnya sebaik-baiknya, dan mebiasakan mereka berpegang teguh pada adab dan kesopanan pada muamalat baik di rumah, atau di sekolah, atau di jalan atau di tempat-tempat bidang yang lain.

h) Menanamkan keimanan yang kuat kepada Allah pada jiwa mereka,dan menguastkan rasa cinta pada agama dan ahlak pada dir mereka.

i) Membersihkan hati mereka daripada dengki, hasad, menyeleweng, kebencian, kekerasan, aniaya, egoisme, tipu khianat, nipaq, raguragu dan perpecahan. ${ }^{26}$

Penggunaan alat-alat mengajar dalam membantu pendidikan sikap dan afektif anak bisa dilakukan dengan menggunakan peta-peta dan gambargambar seperti zakat dan haji.

\section{d. Penilaian $^{27}$}

Penilaian dalam fungsi sebenarnya mempunyai dua fungsi yaitu sebagai pengertian dan sebagai peneguhan. Sebagai pengertian ia memberi podoman bagi guru-guru apakah pengajarannya berhasil atau tidak. Kalau berhasil maka ia meneruskan strategi yang digunakannya, kalau tidak, maka ia harus merobah strateginya supaya mencapai keberhasilan dari segi kognitif, afektif, psikomotor.

\section{${ }^{26}$ Ibid., hlm. 179-180}

${ }^{27}$ Dalam pendidikan, salah satu aspek penilaian digunakan untuk memberi ganjaran kepada murid-murid, seperti ujian ahir tahun untuk kenaikan kelas. Disusuli dengan tiga tahun misalnya untuk ujian yang yang lebih besar. Tujuanya agar waktu yang terlalu lama itu dapat dibagi kepada beberapa bagian supaya jangan membosankan. Keadaan inipun disadari oleh pendidik-pendidik Islam zaman dahulu seperti kita lihat Ibnu Zina, Ibnu Khaldun dan lai sebagainya. Hasan Langgulung, Manusia dan Pendidikan ..., hlm. 67
Sebagai peneguhan maka penilaian itu bertugas mengekalkan sikap dan tingkah laku yang diingini dan menghilangkan tingkah laku yang tidak diingini. Suatu tingkah laku boleh kekal sebab ia diteguhkan supaya ia kekal. Salah satu cara meneguhkannya ialah melalui penilaian, dengan ganjaran dan pujian, atau mungkin dengan angka, sebab kalau tidak diteguhkan lama-lama sikap dan ahlak itu hilang, dan ini berarti pendidikan tidak berhasil.

Penilaian afektif dapat dilakukan di dalam kelas dan di luar kelas, namun penilaian pencapaian dalam kelas saja sangat berat sebelah apalagi dalam kawasan afektif. Kawasan afektif bisa dinilai dari segi aktifitas-aktifitas ektramural, atau keikutsertaan murid dalam kegiatan-kegiatan keagamaan di dalam sekolah.

\section{Pendidikan afektif di lingkungan keluarga}

Kelurga merupakan sebagai lingkungan atau milieu pertama bagi anak dimana ia berinteraksi. Dari milleu pertama itu anak memperoleh unsur ciriciri dasar daripada kepribadiannya. Juga dari situ ia memperoleh ahlak, nilainilai kebiasaan-kebiasaan dan emosinya dan dengan itu, ia merobah banyak kemungkinan-kemungkinan, kesanggupan-kesanggupan dan kesediaanya menjadi kenyataan yang hidup dan tingkah laku yang nampak. ${ }^{28}$ Dan bimbingan, perhatian, dan kasih sayang terjalin antara kedua orang tua dengan anak-anaknya,merupakan basis yang ampuh bagi pertumbuhan dan perkembangan psikis serta nilai-nilai sosial dan religius pada diri anak didik. $^{29}$

Proses sosialisasi penanaman nilai pada diri anak didik menurut Hasan Langgulung secara praktis dimulai sejak anak dilahirkan ${ }^{30}$. Pada fase ini anak

28 Hasan Langgulung, Manusia dan Pendidikan ..., hlm. 348

${ }^{29}$ Hasan Langgulung, Pendidikan Islam dan Peralihan Paradigma, (Selangor: Hizbi Press, 1995), hlm. 14. Bandingkan dengan Abdurrahman An-Nakhlawi, Ushul al-Tarbiah al-Islamiat wa Aslalibiha, (Damsik: Dar al-Fikr, 1983 ), hlm. 139-140

${ }^{30}$ Dalam kontek Islam, secara teoritis upaya penanaman nilai-nilaibpendidikan dimulai sejak awal pemilihan jodoh. Dalam konteks ini, nabi SAW telah memberikan isyarak dengan empat kriteria; karena kecantikannya, kekayaan, keturunannya, dan agamanya. Di antara keempat criteria tersebut,menurut nabi untukterbinanya situasi keluarga sakinah yang Islami, hendaknya menjadikan criteria agama sebagai kriteria utama. Di sisi lain, untuk proses pendidikan pada pase pra natal ini, dianjurkan kepada pasangan 
akan menjadikan perilaku kedua orang tuanya atau keluarganya yang lain, sebagai model dalam perilaku sehari-hari, untuk itu, semakin banyak pengalaman yang bernilai agamis mampu ditransfer dan diterimanya, maka akan semakin banyak pula unsur agama dan pengalaman yang mempu mewarisi proses pembentukan kepribadiannya. ${ }^{31}$

Dalam hal ini, keluarga menurut pandangan individu merupakan simbol bagi ciri-ciri yang mulia seperti keimanan yang teguh kepada Allah, pengorbanan, kesediaan berkorban untuk kelompok, cinta kepada kebaikan, kesetiaan dan lain-lain lagi nilai mulia yang dengannya keluarga dapat menolong individu itu perlu kepada keluarga bukan hanya pada tingkat awal hidupnya dan pada masa kanak-kanak, tetapi ia memerlukan sepanjang hidupnya, sebagai kanak-kanak, remaja, dewasa, orang tua, dan orang tua bangka untuk menanamkan pada dirinya rasa kasih sayang, rasa tenteram, dan ketenangan. ${ }^{32}$ Sebab, orang tidak akan sempat terpelihara dalam suatu keluarga yang wajar dan sehat pada masa-masa pertama akan mengalami akibat yang buruk pada keseluruhan hidupnya dan selalu dahaga kepada kasih sayang dan ketentraman.

Adapun pendidikan di dalam lingkungan keluarga dalam membentuk sikap (afektif) anak didik menurut Hasan Langgulung dibagi kepada empat bagian yaitu:

\section{Pendidikan emosi}

Diantara bidang-bidang di mana keluarga dapat memainkan peranan penting dalam pendidikan emosional adalah menumbuhkan emosi kemanusiaan yang mulia, seperti rasa cinta kepada orang lain, mengasihi orang yang lemah dan teraniaya, menyayangi dan mengasihi orang fakir miskin, kehidupan emosi yang rukun dan orang lain dan sebagainya. ${ }^{33}$

Pentingnya peranan keluarga dalam pendidikan ini adalah sebab ia melibatkan kanak-kanak dalam tahab awal hidupnya, dimana hubunganhubungan dan pengalaman-pengalaman-pengalaman sosialnya belum cukup

suami istri untuk melakukan hubungan dengan sesamanya secara halal dan menyehatkan yang sangat menentukan bagi kelangsungan proses perkembangan janin selanjutnya.

31 Hasan Langgulung, Pendidikan dan Peradaban ..., hlm. 50-51
32 Hasan Langgulung, Manusia dan Pendidikan ..., hlm. 348

${ }^{33}$ Ibid., hlm. 368 luas juga belum sanggup berdikari untuk menggapi suasana yang milieu di sekelilingnya.

\section{Pendidikan Agama dan spiritual.}

Pendidikan agama dan spiritual termasuk bidang-bidang pendidikan yang harus mendapat perhatian penuh oleh keluarga terhadap anak-anaknya. Pendidikan agama dan spiritual berarti membangkitkan kekuatan dan kesediaan spiritual yang bersipat naluri yang ada pada kanak-kanak melalui bimbingan agama yang sehat dan mengamalkan ajaran-ajaran agama dan menolongnya mengembangkan sikap agama yang betul. Yang termasuk mula-mula sekali adalah iman yang keluar kepada Allah, malaikatnya, kitabkitabnya, rasul rasulnya, hari ahirat, kepercayaannya yang kuat, takut kepada Allah, dan selalu mendapat pengawasan daripadannya dalam segala perbuatan dan perkataan ${ }^{34}$.

Di antara cara-cara praktis yang patut digunakan oleh keluarga untuk menanamkan semangat keagamaan pada diri anak-anak adalah dengan cara sebagai berikut :

a) Memberikan tauladan yang baik kepada mereka tentang kekuatan iman kepada Allah dan berpegang dengan ajaran-ajaran agama dalam bentuknya yang sempurna dalam waktu tertentu.

b) Membiasakan mereka menunaikan syiar-syiar agama semenjak kecil sehingga penunaian itu menjadi kebiasaan yang mendarah daging, mereka melakukannya dengan kemauan sendiri dan merasa tentram sebab melakukannya

c) Menyiapkan suasana agama dan spiritual yang sesuai dengan di rumah di mana mereka berada

d) membimbing mereka membaca bacaan agama yang berguna dan memimirkan ciptaan-ciptaan Allah dan mahluk-mahluk untuk menjadi bukti kehalusan system ciptaan itu dan ata wujud keagunganya

e) menggalakkan mereka turut serta dalam aktifitas-aktifitas agama. ${ }^{35}$

Ketika keluarga menunaikan hal-hal tersebut, sebenarnya ia menurut kepada petunjuk dari al-Qur'an, sunnah nabi s.a.w. yang semuanya

\section{Ibid., hlm. 372}

${ }^{35}$ Ibid. 
mengajak untuk melaksanakan pendidikan mengharuskan orang tua mendidik anaknya akan iman dan akidah yang betul dan membiasakan mengerakan syari'at Islam terutama sembahyang.

\section{Pendidikan ahlak bagi anak-anak}

Pendidikan agama berkaitan dengan pendidikan ahlak. Tidak berlebihlebihan dikatakan bahwa pendidikan ahlak dalam pengertian pendidikan Islam adalah bagian yang tidak dapat dipisahkan dalam pendidikan agama. Sebab yang baik adalah yang dianggap baik oleh agama dan yang buruk adalah apa yang dianggap buruk oleh agama. Hampir-hampir sepakat filosof-filosof muslim seperti Ibnu Miskawaih ${ }^{36}$ mengatakan bahwa pendidikan ahlak adalah jiwa pendidikan Islam, sebab tujuan tertinggi pendidikan Islam adalah membentuk jiwanya supaya terwujud sikap yang mampu mendorong serta spontan untuk melahirkan semua perbuatan yang baik. $^{37}$

Keluarga memegang peranan penting sekali dalam pendidikan ahlak untuk anak-anaknya. Oleh sebab itu haruslah keluarga harus mengajarkan mereka tentang ahlak mulia yang diajarkan Islam seperti kejujuran, keikhlasan, kesabaran, cinta kasih sayang dan lain sebagainya. Dan ia juga mengajarkan nilai dan faedahnya berpegang teguh pada ahlak di dalam hidup, sebab manusia sesuai dengan sifat asasinya menerima nasihat jika datangnya melalui rasa cinta dan kasih sayang dan menolaknya jika disertai dengan kekerasan dan biadab.

${ }^{36}$ Nama lengkapnya adalah Ahmad Ibnu Muhammad Ibnu Ya'kub Ibnu Miskawaih. Ia dilahirkan pada tahun 320 H/ 932 M. di Rayyi, dan meninggal di Isfahan pada tanggal 9 shafar 412 H / 16 Februari 1030 M. Ibnu Miskawaih hidup pada masa pemerintahan dinasti Buwaih yang sebahagian pemukanya bermazhab Syi'ah. Ibnu Miskawaih adalah bendaharawan, sekretaris, pustakawan dan pendidikan anak para pemuka dinasti Buwaih. Selain akrab dengan penguasa, ia juga banyak bergaul dengan para ilmuan seperti Abu Hayyan at-Tauhidi, Yahya Ibnu Adi dan Ibnu Zina. Selain itu ia juga dikenal sebagai sejarawan yang besar yang kemashurannya melebihi para pendahulunya. Selanjutnya ia juga dikenal sebagai dokter, penyair dan ahli bahasa. Lihat Hasan Tamim " al-Muqaddimah" dalam Tatbir al-A'raq, (Beirut: Mansyurat Dar al Maktabah al-Hayat, 1398 H ), hlm. 5-8. M Syarif, A History of Muslim Fbilosofy, (Weisbaden: Otto Harrosowth, 1963), Vol. I, hlm. 469

${ }^{37}$ Abudin Nata, Pemikiran Para Tokoh Pendidikan Islam, Segi Kajian Filsafat Pendidikan Islam, (Jakarta: Grafinso Persada, 2003), hlm. 11
Diantara kewajiban keluarga dalam dalam pendidikan ahlak menurut Hasan Langgulung adalah:

a) Memberikan contoh yang baik bagi anak-anaknya dalam berpegang teguh kepada ahlah mullia sebab orang tua yang tidak berhasil menilai dirinya tentulah tidak sanggup meyakinkan anak-anaknya untuk memegang ahlak yang diajarkanya.

b) Menyediakan bagi anak-anak peluang-peluang dan suasana praktis dimana mereka dapat memperaktekkan ahlak yang diterima dari orang tuanya.

c) Memberi tanggung jawab sesuai kepada anak-anaknya supaya mereka bebas memilih dalam tindak tanduknya.

d) Mengawasi mereka dengan sadar dan bijaksana ${ }^{38}$

\section{Pendidikan sosiologi}

Keluarga belum melengkapi tugasnya dengan sempurna dalam pendidikan anak-anak sehingga ia menolong anak-anak bertumbuh dari segi sosial. Pendidikan sosial ini melibatkan bimbingan terhadap sikap dan tingkah laku sosial, ekonomi, politik dalam rangka ekonomi Islam yang betul dan ajaran-ajaran agama yang berusaha meningkatkan iman, taqwa, takut kepada Allah dan mengerjakan agama-agamanya yang mendorong kepada produksi, menghargai waktu, jujur, ikhlas dalam perbuatan, adil, kasih sayang, ihsan, mementingkan orang lain, tolong menolong, setia kawan dan lain-lain lagi dalam membentuk sikap yang mempunyai nilai-nilai sosial

Proses sosialisasi berlaku semenjak kanak-kanak masih bayi. Dalam masa ini agen sosialisasi satu-satunya adalah ibu bapak. Apa yang dikatakan dibuat, dilarang, oleh orang tua dituruti si anak dengan segala senang hati. Tetapi kalau si anak memperhatikan ada pertentangan sikap orang tuanya, maka si anak menjadi bingung, yang menjadi si anak membantah dan mendurhakai orang tuanya. ${ }^{39}$

Ada lagi suatu faktor lain yang yang mempengaruhi proses sosialisasi anak dan syahsiah anak-anak yaitu yaitu sikap (attitude) ibu bapak terhadap apa yang dibuat, dikatakan dan diperintahkan. Pertama sekali perkataan dan

${ }^{38}$ Ibid., hlm. 374

${ }^{39}$ Hasan Langgulung, Pendidikan dan Peradaban ..., hlm. 51 
perbuatan itu mesti timbul dari hati yang suci dan bersih, atau dengan kata lain apa yang dikatakan dan dibuat itu timbul dari keyakinan dan keimanan, bukan dari sipat pura-pura. Misalnya berpura-pura sembahyang supaya anak anak ikut sembahyang.

Di antara cara-cara yang patut digunakan oleh keluarga menurut Hasan Langgulung dalam mendidik anak-anaknya dari segi sosial, politik, dan ekonomi adalah :

a) memberi contoh yang baik kepada anak-anaknya dalam tingkah laku sosial yang sehat berdasarkan prinsip-prinsip dan nilai-nilai agama

b) menjadikan rumah itu sebagai tempat dimana tercipta hubunganhubungan sosial yang berhasil

c) membiasakan anak-anaknya secara berangsur-angsur berdikari dan memikul tanggung jawab dan membimbingnya jika mereka bersalah dan lemah lembut.

d) menjauhkan mereka dari sipat manja dan berpoya-poya dan jangan menghina dan merendahkan mereka dengan kasar sebabb sikap memanjakan dan kekerasan itu merusak kepribadian anak-anak.

e) memperlakukan mereka dengan lemah lembut dengan menghormatinya di depan kawan-kawannya tetapi jangan melepaskan kekuasaan kebapaan mereka terhadap anak-anaknya

f) menolong anak-anaknya menjalin persahabatan yang mulia dan berhasil, sebab manusia turut menjadi baik karena berkawan dengan orang sholeh.

g) menggalakkan mereka mendapatkan kerja yang dapat menolong mereka berdikari dari segi ekonomi dan emosi.

h) membiasakan mereka hidup sederhana supaya lebih sedia menghadapi kesulitan hidup sebelum terjadi

i) bersipat adil diantara mereka

j) bembiasakan mereka dengan cara-cara Islam dalam makan, minum, duduk, tidur, memberi salam, masuk rumah yang telah didiami orang dan lain-lain.

\section{Kesimpulan}

${ }^{40}$ Ibid., hlm. 52
Pendidikan afektif menurut Hasan Langgulung adalah .pembentukan dan pembinaan anak didik yang bertujuan untuk untuk membina kakarter dan kepribadiannya bukan daya pikirnya. Pembentukan sikap anak didik secara praktis dimulai sejak anak dilahirkan. Karena, pada pase ini anak akan menjadikan orang tuanya sebagai model dalam perilaku sehari hari. Berarti, semakin banyak model yang diberikan contoh kepadanya, maka, semakin banyak pula sikap dan pengalaman yang mempengaruhi pembentukan kepribadiannya. Pendekatan pendidikan afektif dilingkungan sekolah dan keluarga dapat dilakukan dengan menggunakan pendekatan berpusat pada anak/siswa dan pendekatan yang berpusat pada orang tua/guru. Disebut berpusat pada orang tua/guru dimana orang tua/guru dijadikan figur yang harus dicontoh dan diteladani. Disebut berpusat kepada kepada anak/siswa dimana anak menjadi objek yang dibiasakan dengan sikap-sikap yang positif. Strategi pendidikan afektif dapat dilakukan dengan modeling, yaitu pembentukan sikap melalui proses asimilasi atau proses pencontohan. atau dengan strategi pembelajaran kognitif artinya sikap anak dibentuk dengan pengembangan kognitif. Metode pendidikan afektif yang yang digunakan Hasan Langgulung baik di lingkungan formal maupun non formal dalam pembentukan sikap anak dapat dilakukan dengan metode pembiasaan, amsal, keteladanan, partisipasi, bimbingan, dan latihan.

\section{Bibliografi}

An-Nahlawi, Abdurrahman Ushul at-Tarbiyah al-Islamiyah wa asalibuha Damaskus : Dar al-fikr, 1988.

Al-Toumy al-Syaibany, Omar Muhammad, Falsafah Pendidikan Islam, Terj Hasan Langgulung, Jakarta: Bulan Bintang, 1979

Indonesia Educational Statistic in Brief 2000/2001: Balitbang Depsiknas dikutif dari harian Media Indonesia, 28 Maret 2011

Kunandar, Guru Propesional Implementasi Kurikulum Tingkat Satuan Pendidikan (KTSP) dan Dalam Sertifikasi Guru, Jakarta : Rajawali Press, 2007

Langgulung Hasan, Manusia dan pendidikan suatu analisa psikologi dan pendidikan, Jakarta : al-husna Zikra, 1996.

Beberapa Aspek Pendidikan ditinjau dari segi Islam, Kuala Lumpur Dewan Masyarakat, 1997. 
Al-Fikra: Jurnal Ilmiah Keislaman, Vol. 12, No. 1, Januari - Juni, 2013

Beberapa pemikiran tentang pendidikan Islam, Bandung : alMaa'arif, 1980.

, Asas-asas Pendidikan Islam , Jakarta : Pustaka al-Husna Baru, 2003. 2003.

Pendidikan Islam Abad 21, Jakarta: Pustaka al-Husna Baru,

, Kreativitas dan Pendidikan Islam Analisa Psikologi dan Falsafah, Jakarta : Pustaka al-Zikra, 1991.

1985

, Teori-teori kesehatan mental, Jakarta: al-Husna Zikra, 1986.

Nata, Abuddin, ,Pemikiran Para Tokoh Pendidikan Islam, Segi Kajian Filsafat Pendidikan Islam, ( Jakarta : Grafinso Persada, 2003.

Sanjaya, Wina, Strategi Pembelajaran Berorientasi Standar Proses Pendidikan, Jakarta:Kencana Prenada Media Group, 2007

Tamim, Hasan “ al-Muqaddimah” dalam Tathir al-A'raq, Beirut : Mansyurat Dar al Maktabah al-Hayat, $1398 \mathrm{H}$

Who's Who in The Word, 7 Edition 1984-1985, Chicago IIIiniois: Marquis Who's Who Incorporated, 1984 